OPEN ACCESS

Edited by:

Julian Blasco,

Consejo Superior de Investigaciones Cientificas (CSIC), Spain

Reviewed by: Srikanth Koigoora, University of Aveiro, Portugal Paolo Cocci,

University of Camerino, Italy

${ }^{*}$ Correspondence:

Rachel Ann Hauser-Davis rachel.hauser.davis@gmail.com; rachel.davis@ioc.fiocruz.br

Specialty section: This article was submitted to Marine Pollution,

a section of the journal Frontiers in Marine Science

Received: 16 November 2020 Accepted: 08 February 2021

Published: 18 March 2021

Citation:

Bruno DdA, Willmer IQ, Pereira LHSdS, Rocha RCC,

Saint'Pierre TD, Baldassin P, Scarelli ACS, Tadeu AD, Correia FV, Saggioro EM, Lemos LS, Siciliano $S$ and Hauser-Davis RA (2021) Metal and Metalloid Contamination in Green

Sea Turtles (Chelonia mydas) Found

Stranded in Southeastern Brazil.

Front. Mar. Sci. 8:608253.

doi: 10.3389/fmars.2021.608253

\section{Metal and Metalloid Contamination in Green Sea Turtles (Chelonia mydas) Found Stranded in Southeastern Brazil}

Daphne de Albuquerque Bruno, 1,2, Isabel Q. Willmer ${ }^{2,3}$, Lucia Helena S. de S. Pereira ${ }^{2,4}$, Rafael C. C. Rocha4, Tatiana D. Saint'Pierre4, Paula Baldassin' ${ }^{5}$, Ana Carolina S. Scarelli6, Amanda Dias Tadeu, Fábio V. Correia ${ }^{1,7}$, Enrico M. Saggioro ${ }^{1,8}$, Leila S. Lemos ${ }^{9,10}$, Salvatore Siciliano ${ }^{10,11}$ and Rachel Ann Hauser-Davis ${ }^{2 *}$

'Programa de Pós-Graduação em Saúde Pública e Meio Ambiente, Escola Nacional de Saúde Pública Sérgio Arouca, Fiocruz, Rio de Janeiro, Brazil, ${ }^{2}$ Laboratório de Avaliação e Promoção da Saúde Ambiental, Instituto Oswaldo Cruz (Fiocruz), Rio de Janeiro, Brazil, ${ }^{3}$ Laboratório de Biologia e Tecnologia Pesqueira, Centro de Ciências da Saúde, Instituto de Biologia, Departamento de Biologia Marinha, Universidade Federal do Rio de Janeiro, Rio de Janeiro, Brazil, ${ }^{4}$ Departamento de Química, Pontifícia Universidade Católica do Rio de Janeiro, Rio de Janeiro, Brazil, ${ }^{5}$ BW Consultoria Veterinária, Araruama, Brazil, ${ }^{6}$ CTA Serviços em Meio Ambiente, Vitória, Brazil, ${ }^{7}$ Laboratório de Saúde Ambiental, Departamento de Ciencias Naturais, Universidade Federal do Estado do Rio de Janeiro, Rio de Janeiro, Brazil, ${ }^{8}$ Departamento de Saneamento e Sauide Ambiental, Escola Nacional de Saúde Pública Sérgio Arouca, Fiocruz, Rio de Janeiro, Brazil, ${ }^{9}$ Institute of Environment, Florida International University, Miami, FL, United States, ${ }^{10}$ Grupo de Estudos de Mamíferos Marinhos da Região dos Lagos, Araruama, Brazil, ${ }^{11}$ Fundação Oswaldo Cruz (Fiocruz), Rio de Janeiro, Brazil

Sea turtles tend to accumulate high metal levels in their tissues and are considered excellent pollution bioindicators. Studies concerning metal contamination in hatchlings, however, are non-existent for one of the most abundant species in Brazil, green sea turtles, while several other metal assessments in juvenile muscles are still scarce. In this context, this study aimed to analyze the concentrations of 12 elements in kidney and muscle samples from green sea turtles (Chelonia mydas; $n=24$ ) found stranded in Rio de Janeiro, southeastern Brazil. Elemental concentrations were determined by inductively coupled plasma mass spectrometry (ICP-MS). The presence of fibropapillomatosis, an increasingly common disease in sea turtles which has been associated to metal contamination, was also evaluated. Most elements (Mn, Fe, $\mathrm{Co}, \mathrm{Ni}, \mathrm{Cu}, \mathrm{Zn}, \mathrm{Cd}, \mathrm{Hg}$, and $\mathrm{Pb}$ ) were significantly higher in liver, while $\mathrm{Al}$ and $\mathrm{As}$ were significantly higher in muscle tissue, indicating bioaccumulation of the latter two elements. No differences between juvenile male and female green turtles were observed for either liver or kidney concerning the investigated elements. Literature comparisons of studies conducted in other areas throughout the Brazilian coast indicate higher concentrations of $\mathrm{Cd}, \mathrm{Mn}, \mathrm{As}, \mathrm{Hg}$, and $\mathrm{Zn}$ in kidneys, of probable anthropogenic origin. Several statistically significant inter-elemental correlations were observed between toxic elements, indicating similar sources for these environmental contaminants. Significant correlations between $\mathrm{Hg}$ in muscle and kidney and As in the same organs suggest bioaccumulation of both elements in muscle. Three individuals 
assessed herein exhibited fibropapillomatosis, and further assessments in this regard and potential correlations to the detected metal concentrations are currently being carried out. In addition, evaluations concerning other toxic compounds, as well as deleterious cellular effects, are also underway, since total metal concentrations do not reflect total elemental bioavailability.

Keywords: metal contamination, Chelonia mydas, fibropapillomatosis, environmental health, bioindicator

\section{INTRODUCTION}

Among environmental pollutants generated by anthropogenic activities, metals are of significant concern due to their environmental persistence and potential toxicity (Marins et al., 1998; Marcovecchio, 2000; Baird, 2002; Miller et al., 2002; Melo, 2003).

Long lived animals, such as sea turtles, tend to accumulate higher levels of metals in their tissues compared to the water column (De la Lanza-Espino et al., 2000; Aguilar et al., 2002), and are, thus, considered competent chemical contamination indicators (Caurant et al., 1999). Exposure to metals, in general, has been associated with turtle enzyme inactivation and protein denaturing, causing deleterious effects such as developmental disorders, neurological damage, carcinogenic effects, and death (Fossi and Marsili, 2003; Decataldo et al., 2004; De Jesus and de Carvalho, 2008; Marijić et al., 2016). In addition to deleterious biochemical effects, sea turtles have also been reported to develop fibropapillomatosis due to contaminant exposure, including metals (Keller et al., 2014; Da Silva et al., 2016), and higher frequencies of fibropapillomatosis have been reported in contaminated environments (Formia et al., 2007; Guimarães et al., 2013), indicating a potential link between chemical environmental contamination, oxidative stress, dysregulation of metabolic functions and the consequent development of this disease. This condition is caused by a herpesvirus and, in turtles, is characterized by the appearance of tumor masses on different parts of the body, such as the oral cavity, eyes, skin, carapace and, in about $25-30 \%$ of affected individuals, internal organs (Herbst, 1994; Aguirre et al., 2002; Aguirre and Lutz, 2004).

Of the seven species of sea turtle found worldwide, five are found throughout the Brazilian coast, constituting two families, Cheloniidae, comprising Chelonia mydas (green turtles), Eretmochelys imbricata (hawksbill turtles), Caretta caretta (loggerhead turtles), and Lepidochelys olivacea (olive ridley turtles), and Dermochelyidae, comprising Dermochelys coriacea (leatherback turtles) (Marcovaldi and Dei Marcovaldi, 1999). All are classified as vulnerable, threatened or critically endangered, according to the International Union for Conservation of Nature (IUCN, 2020). The most frequent and abundant species in Brazil are green sea turtles (Bezerra et al., 2012). Green sea turtle hatchlings exhibit a pelagic phase lasting for about 5-10 years, during which they remain associated with pelagic currents (Musick and Limpus, 1997), while juveniles generally recruit to developmental habitats prior to moving to adult feeding grounds (Arthur et al., 2008). Unfortunately, many sea turtle nesting and feeding areas in Southeastern Brazil are located in highly urbanized areas (De Macêdo et al., 2015), exposing these animals to contaminants originated from anthropogenic activities during all development stages. Studies concerning metal contamination during different turtle development stages, however, are scarce in general. Furthermore, assessments concerning metal levels in kidney and muscle samples from green sea turtle hatchlings are extremely infrequent in Brazil, while a scarcity of metal assessments for juvenile muscle tissue in general is noted. In this context, this study aimed to analyze the concentrations of 12 metals and metalloids in kidney and muscle samples of male and female hatchling and juvenile green sea turtle individuals found stranded in the state of Rio de Janeiro, southeastern Brazil and perform preliminary associations between the presence of these contaminants and the development of fibropapillomatosis.

\section{METHODOLOGY}

\section{Study Area}

The study area is located in the state of Rio de Janeiro, 200 southeastern Brazil, in the Região dos Lagos region, which 201 comprises the municipalities of Maricá, Saquarema, Araruama, 202 São Pedro da Aldeia, Cabo Frio, Arraial do Cabo, Iguaba Grande, 203 Armação dos Búzios, Casimiro de Abreu, and Rio das Ostras (Figure 1). This region suffers the influence of ports and oil platforms in adjacent areas, as well as increasing urbanization in recent years. In addition, during certain periods of the year, the Região dos Lagos receives a high number of tourists, significantly impacting the marine environment, as high volumes sewage, solid waste and contaminants are directly discharged into local water bodies (Da Silva et al., 2018).

\section{Sea Turtle Sampling and Processing}

Green sea turtles were found stranded during regular beach monitoring, carried out twice a day from January to December 2019 at Região dos Lagos. Geographic coordinates, time, and carcass conditions were recorded. Carcass weight, curved carapace length (CCL), and curved carapace width (CCW) were determined (Frazer and Ehrhart, 1985). Juveniles were categorized as those displaying over $20 \mathrm{~cm}$ CCL and less than 90-100 cm, when sexual maturity is reached (Heppell et al., 2003; Reich et al., 2007). Fibropapillomatosis was detected through visual inspection of external masses by experienced veterinarians (presence or absence of external tumor masses). Sex was determined through visual macroinspection of the gonads during necropsies, according to Wyneken (2001). After the biometric analyses, the animals were dissected through standardized procedures (Wyneken, 2001), and muscle and kidney samples were obtained. The tissue samples were stored 


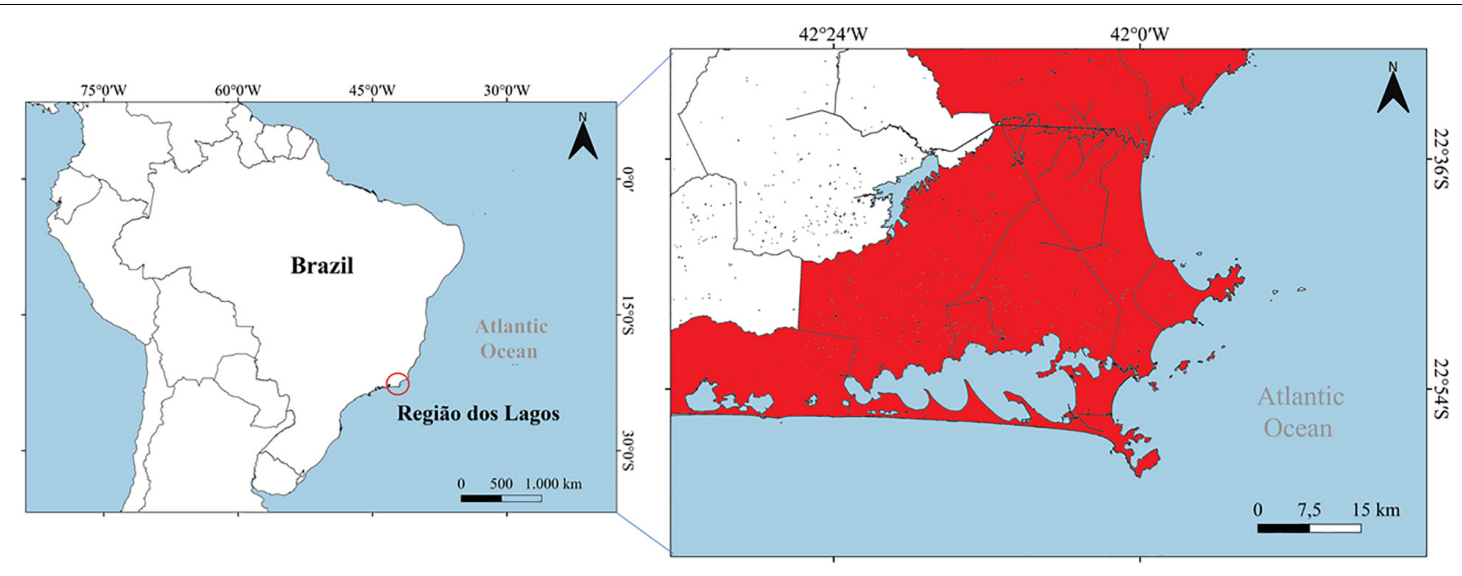

FIGURE 1 | Map of the study area of Região dos Lagos, eastern coast of the state of Rio de Janeiro, southeastern Brazil.

TABLE 1 | ICP-MS instrumental operating conditions applied in elemental determinations in green turtle (Chelonia mydas) muscle and kidney samples.

\begin{tabular}{lc}
\hline ICP-MS parameter & Condition \\
\hline RF power & $1100 \mathrm{~W}$ \\
Plasma gas flow rate & $17.0 \mathrm{~L} \mathrm{~min}^{-1}$ \\
Auxiliary gas flow rate & $1.2 \mathrm{~L} \mathrm{~min}^{-1}$ \\
Carrier gas flow rate & $0.98 \mathrm{~L} \mathrm{~min}^{-1}$ \\
Sampling and skimmer cones & $\mathrm{Pt}$ \\
Dwell time & $50 \mathrm{~ms} \mathrm{per} \mathrm{isotope}$ \\
Number of readings & 5 \\
\hline
\end{tabular}

separately in sterile polypropylene tubes and frozen at $-80^{\circ} \mathrm{C}$ until further processing. Authorization for sampling and analyses of the stranded sea turtles was given by the Brazilian Ministry of Environment (ABIO license no. 861/2017). No ethics committee authorization in Brazil is required for the analyses of animals found dead.

\section{Total Elemental Determinations}

Samples were thawed and approximately $150 \mathrm{mg}$ of each were weighed, transferred to new sterile $15 \mathrm{~mL}$ polypropylene tubes and mixed with $1.5 \mathrm{~mL}$ of bidistilled nitric acid $\left(\mathrm{HNO}_{3}, 67 \%\right.$ $\mathrm{v} / \mathrm{v})$. The samples were then heated to $100^{\circ} \mathrm{C}$ in the capped (closed) polypropylene tubes for approximately $4 \mathrm{~h}$, avoiding loss of volatile elements, such as As and Hg (USP, 2013). After cooling, samples were adequately diluted with Milli-Q water (resistivity >18.0 $\mathrm{M} \Omega \mathrm{cm}$ ) obtained from a Merck Millipore water purifying system (Darmstadt, Germany), for subsequent analysis by inductively coupled plasma mass spectrometry (ICPMS), employing a NexIon 300X spectrometer (PerkinElmer, United States). Multielemental external calibration was applied by appropriate dilutions of a mixed standard solution (Merck IV) and ${ }^{103} \mathrm{Rh}$ was used as the internal standard from a $20 \mathrm{mg} \mathrm{L}^{-1}$ solution introduced online. All determinations were performed in triplicate. Analytical curve correlation coefficients were always above 0.995 . The instrumental ICP-MS conditions are displayed in Table 1.
TABLE 2 | Limits of detection (LOD) and limits of quantification (LOQ) for each element investigated herein in green turtle (Chelonia mydas) muscle and kidney samples.

\begin{tabular}{lcc}
\hline Element & LOD $\left(\mathbf{m g ~} \mathbf{~ g}^{-\mathbf{1}}\right)$ & LOQ $\left.\mathbf{( m g ~} \mathbf{~ g ~}^{-\mathbf{1}}\right)$ \\
\hline $\mathrm{Al}$ & 0.29 & 0.99 \\
$\mathrm{As}$ & 0.002 & 0.008 \\
$\mathrm{Ag}$ & 0.0005 & 0.0017 \\
$\mathrm{Cd}$ & 0.0001 & 0.0002 \\
$\mathrm{Co}$ & 0.0002 & 0.0006 \\
$\mathrm{Cu}$ & 0.017 & 0.055 \\
$\mathrm{Fe}$ & 0.50 & 1.65 \\
$\mathrm{Hg}$ & 0.009 & 0.028 \\
$\mathrm{Mg}$ & 0.29 & 0.99 \\
$\mathrm{Mn}$ & 0.002 & 0.006 \\
$\mathrm{Na}$ & 0.050 & 0.168 \\
$\mathrm{Ni}$ & 0.0015 & 0.0050 \\
$\mathrm{~Pb}$ & 0.010 & 0.035 \\
$\mathrm{Zn}$ & 0.013 & 0.042 \\
\hline
\end{tabular}

TABLE 3 | Observed and certified concentrations $\left(\mathrm{mg} \mathrm{kg}^{-1}\right)$ for the ERMBB422 certified reference material and elemental recoveries (\%).

\begin{tabular}{lccc}
\hline Element & Certified value & Observed value & \% Recovery \\
\hline $\mathrm{As}$ & $12.7 \pm 0.7$ & $15.7 \pm 0.7$ & 124 \\
$\mathrm{Cd}$ & $0.0075 \pm 0.0018$ & $0.0049 \pm 0.0024$ & 66 \\
$\mathrm{Cu}$ & $1.67 \pm 0,16$ & $1.62 \pm 0.09$ & 97 \\
$\mathrm{Fe}$ & $9.4 \pm 1.4$ & $9.8 \pm 2.8$ & 104 \\
$\mathrm{Hg}$ & $0.601 \pm 0.030$ & $0.701 \pm 0.049$ & 116 \\
$\mathrm{Mg}$ & 1370 & $1330 \pm 38.74$ & 97 \\
$\mathrm{Na}$ & 2800 & $2665 \pm 114$ & 95 \\
$\mathrm{Zn}$ & $16 \pm 1.1$ & $16 \pm 0.7$ & 99 \\
\hline
\end{tabular}

The limits of detection (LOD) and limits of quantification (LOQ) for each investigated element were calculated according to the Brazilian National Institute of Metrology, Quality and Technology (Inmetro, 2016) using the following equations: $\mathrm{LOQ}=(3 \times \operatorname{DSDP} \times \mathrm{df}) /$ slope of the line and 
$\mathrm{LOQ}=(10 \times \mathrm{SD} \times \mathrm{df}) /$ slope of the line, where $\mathrm{SD}$ is the standard deviation of the ratio of the analytical signal to the internal standard signal of 10 blanks and $\mathrm{df}$ is the applied sample dilution factor. The determined LOD and LOQ for each investigated element in the present study are displayed in Table 2.

Method accuracy was verified by the parallel analysis of procedural blanks and of a certified reference material (ERMBB422 - fish tissue, European Commission), in triplicate. Table 3 displays the observed and certified values for the ERMBB422 certified reference material and elemental recovery percentages. The volatile elements determined herein (As and $\mathrm{Hg}$ ) presented slightly higher concentrations than the certified values, demonstrating that the sample preparation procedure is efficient and not prone to losses. In addition, the concentrations are also higher than the limits of quantification of the technique obtained through direct introduction of the sample solution. Therefore, it is not necessary to employ the vapor generation technique, which is more time- and reagent- consuming. Certified reference material recovery values were considered adequate for this type of study, as per Eurachem standards (Eurachem, 1998; Ishak et al., 2015).

\section{Statistical Analyses}

Data normality was assessed by the Shapiro-Wilk normality test. As data displayed a non-gaussian distribution, Spearman's correlation test was used to evaluate the degree of associations between the determined elements and CCL, and between element pairs. Only strong and very strong correlations were evaluated, according to Bryman and Cramer (2011). The MannWhitney test was used to assess differences between elemental concentrations among organs and between males and females. Potential differences regarding metal concentrations between the three juvenile individuals presenting fibropapillomatosis and the other juveniles were evaluated by the Kruskal-Wallis test. The significance level for all statistical tests was set at $p<0.05$. The statistical analyses were performed using the $\mathrm{R}$ software (version 3.5.0) R Core Team (2019).

\section{RESULTS}

\section{Sea Turtle Stranding Locations}

A total of 24 stranded green sea turtles were obtained. The sea turtle stranding locations within the oil fields and exploration blocks located at the Campos Basin are exhibited in Figure 2.

\section{Morphobiometric Results}

The morphobiometric data and the presence or absence of fibropapillomatosis of the assessed green turtles are exhibited in Table 4. Concerning sex, $75 \%$ of the individuals were female and $25 \%$ males. Regarding maturity, most (87.5\%) were juveniles and $12.5 \%$ were hatchlings. Of the 24 individuals, only three $(12.5 \%)$ presented fibropapillomatosis. CCL and CCW means for hatchlings were of $26.87 \pm 0.47 \mathrm{~cm}$ and

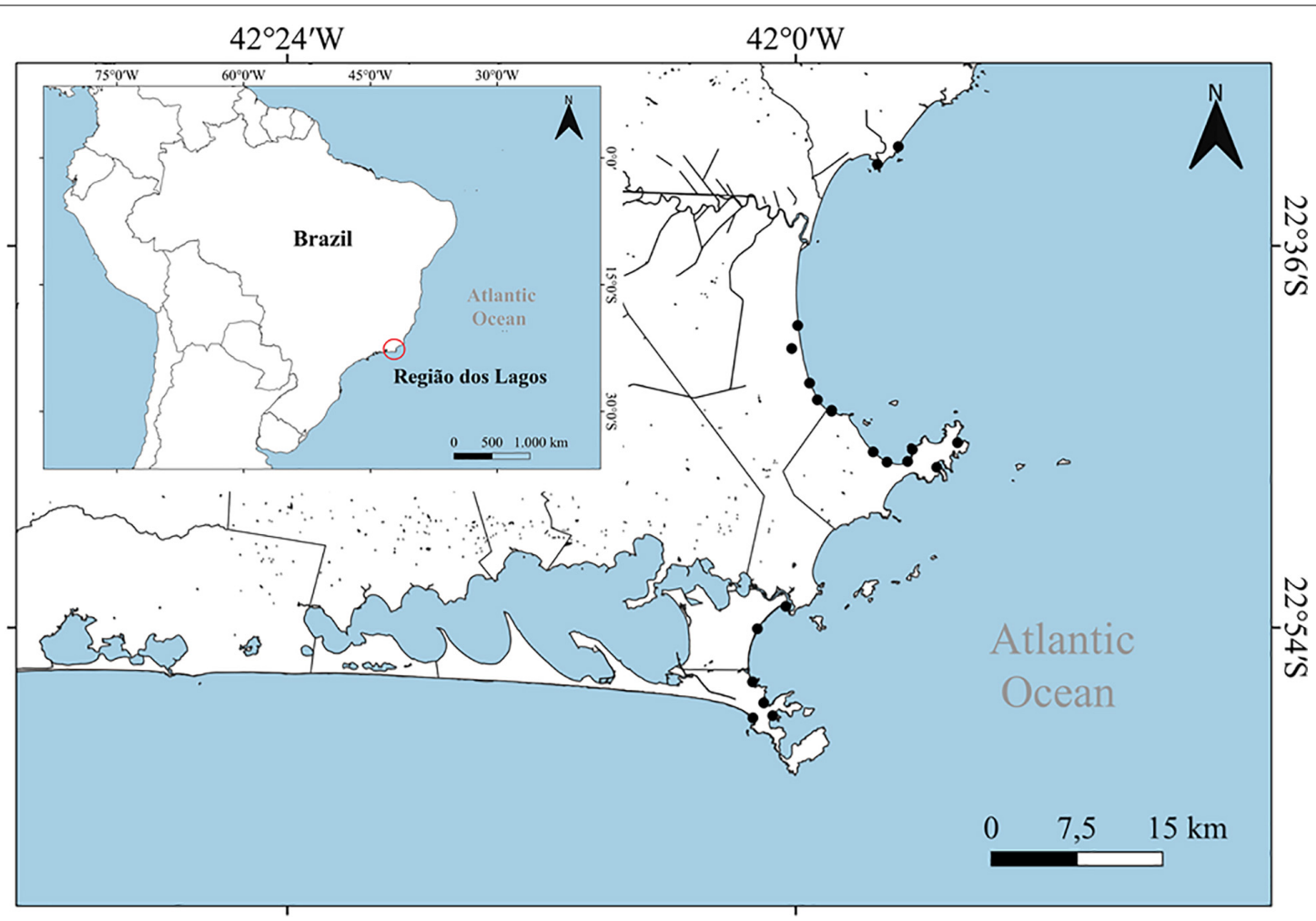

FIGURE 2 | Location of the green sea turtle strandings in the Região dos Lagos region, eastern coast of the state of Rio de Janeiro, southeastern Brazil. 
TABLE 4 | Morphobiometric results of the evaluated sea turtles, indicating, sex, maturation (according to CCL), curved carapace length (CCL, in cm), curved carapace width (CCW, in $\mathrm{cm}$ ), and presence or absence of fibropapillomatosis.

\begin{tabular}{|c|c|c|c|c|c|c|}
\hline Code & Sex & Maturation stage & CCL $(\mathrm{cm})$ & $\mathrm{CCW}(\mathrm{cm})$ & Fibropapillomatosis & Decomposition scale \\
\hline $\mathrm{T} 1$ & Female & Juvenile & 32 & 27.8 & Absent & 2 \\
\hline $\mathrm{T} 2$ & Female & Juvenile & 29.8 & 28.3 & Absent & 2 \\
\hline T3 & Female & Juvenile & 35.9 & 35.5 & Absent & 2 \\
\hline T4 & Female & Juvenile & 35.2 & 31.2 & Absent & 2 \\
\hline $\mathrm{T} 5$ & Female & Juvenile & 38.9 & 34.6 & Absent & 2 \\
\hline T6 & Female & Hatchling & 26.5 & 25.2 & Absent & 2 \\
\hline $\mathrm{T} 7$ & Female & Juvenile & 57.4 & 50.7 & Present & 3 \\
\hline T8 & Female & Juvenile & 35.5 & 32.5 & Absent & 2 \\
\hline T9 & Female & Juvenile & 34.5 & 30.4 & Absent & 3 \\
\hline $\mathrm{T} 10$ & Female & Juvenile & 32.5 & 31.5 & Absent & 4 \\
\hline $\mathrm{T} 11$ & Female & Juvenile & 39.9 & 35.7 & Absent & 3 \\
\hline $\mathrm{T} 12$ & Female & Juvenile & 29.8 & 28.4 & Absent & 2 \\
\hline $\mathrm{T} 13$ & Male & Hatchling & 26.7 & 24.9 & Absent & 3 \\
\hline $\mathrm{T} 14$ & Male & Juvenile & 33.8 & 30.5 & Absent & 2 \\
\hline $\mathrm{T} 15$ & Female & Juvenile & 39.9 & 36.1 & Absent & 3 \\
\hline T16 & Female & Juvenile & 34.7 & 31 & Absent & 2 \\
\hline $\mathrm{T} 17$ & Male & Juvenile & 40.6 & 36.3 & Absent & 2 \\
\hline T18 & Female & Hatchling & 27.4 & 25.2 & Absent & 2 \\
\hline T19 & Male & Juvenile & 32.2 & 29.3 & Absent & 2 \\
\hline T20 & Male & Juvenile & 52.9 & 45.8 & Present & 2 \\
\hline $\mathrm{T} 21$ & Female & Juvenile & 38.9 & 36.4 & Absent & 2 \\
\hline T22 & Female & Juvenile & 33.7 & 29.8 & Absent & 2 \\
\hline T23 & Female & Juvenile & 34 & 30.3 & Present & 3 \\
\hline T24 & Male & Juvenile & 37.2 & 34.2 & Absent & 2 \\
\hline
\end{tabular}

$25.10 \pm 0.17 \mathrm{~cm}$, while juveniles measured $37.11 \pm 6.8 \mathrm{~cm}$ and $33.63 \pm 5.67 \mathrm{~cm}$, respectively.

\section{Elemental Determinations}

Elemental concentrations in green turtle muscle tissue and kidneys are exhibited in Figures 3, 4. The concentrations of most elements ( $\mathrm{Mn}, \mathrm{Fe}, \mathrm{Co}, \mathrm{Ni}, \mathrm{Cu}, \mathrm{Zn}, \mathrm{Cd}, \mathrm{Hg}$, and $\mathrm{Pb}$ ) were significantly $(p<0.05)$ higher in kidney when compared to muscle samples. In contrast, $\mathrm{Al}$ and As were significantly $(p<0.05)$ higher in muscle tissue. This seems to indicate inefficient detoxification of these elements by the liver and kidney routes, thus resulting in muscle bioaccumulation. This is due to the fact that these contaminants are generally lipophilic and usually detoxified first by the liver, followed by kidneys and only then, if present in high concentrations above organic-specific detoxification thresholds, do they accumulate in muscle (Hall et al., 1989; Becker and Bigham, 1995; Taylor et al., 2017).

No significant differences in concentrations were observed between male and female green turtle juveniles in liver or kidney for all investigated elements in the present study. Most studies report no differences in feeding strategies between adult males and females (Barbieri, 2009; Prior et al., 2015; Stokes et al., 2019). One of these studies compared the diets of males, gravid females and non-gravid females from the Western Indian Ocean (Republic of Seychelles), and reported only differences between the gravid and non-gravid females, where seagrass accounted for $95 \%$ of gut content biomass for both males and nonbreeding females, but only $58 \%$ for gravid females, alongside substrate (14\%), and macroalgae (13\%) contents (Stokes et al., 2019). Juvenile assessments, however, are rarer. One assessment indicated no difference between green turtle juvenile and adult feeding habits in seagrass habitats by applying last-bite diet and stable isotope analyses within Port Curtis, QLD, Australia (Prior et al., 2015), although the authors did not assess differences between male and female juveniles.

Generally higher concentrations in juveniles compared to hatchlings were observed for $\mathrm{Ag}, \mathrm{Al}, \mathrm{Cu}, \mathrm{Fe}, \mathrm{Hg}, \mathrm{Ni}, \mathrm{Pb}$, and $\mathrm{Zn}$. This is expected, as green turtle hatchlings, which remain associated with pelagic currents for a number of years (Musick and Limpus, 1997), shift their dietary niche from omnivorous, feeding on neustonic material, to herbivorous in their juvenile and adult stages, when they feed on macroalgae, sea grass and/or mangrove material (Bjorndal, 1997; Cardona et al., 2010), favoring environmental contaminant biomagnification. In addition, juveniles inhabit a slightly differential niche than adult individuals, of shallower habitats and amongst mangroves, with higher abundance of macroalgae, while adults inhabit deeper channels, feeding on deeper seagrass beds (Limpus et al., 2005).

No statistically significant correlations were observed between the concentrations of the determined elements in both muscle and kidney and turtle CCL. This is in agreement with previous assessments (Gardner et al., 2006), but in contrast with other reports indicating negative correlations between CCL and Cd 

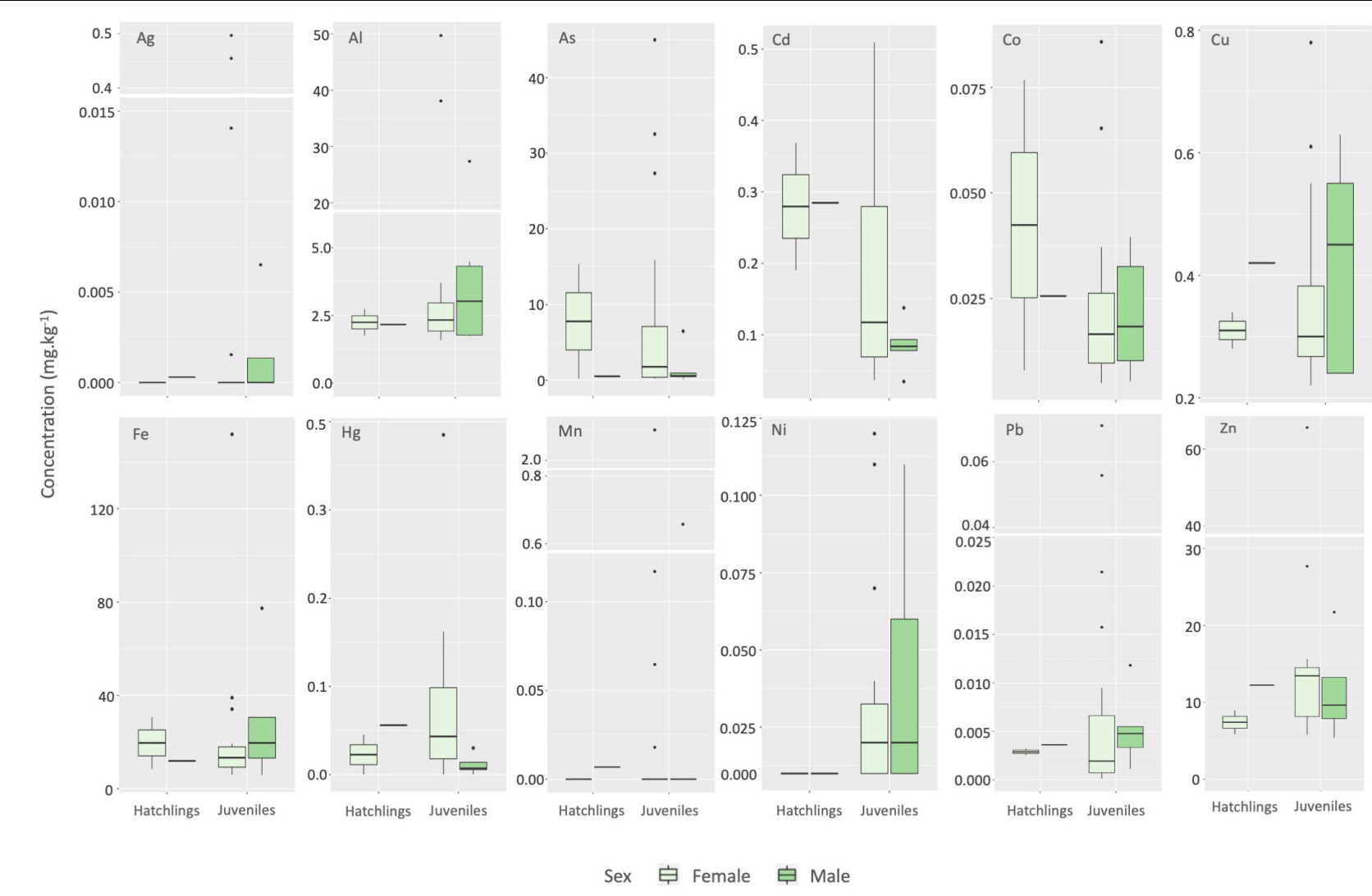

FIGURE 3 | Box plots representing elemental concentration variations in green turtle (Chelonia mydas) muscle tissue. Black dots indicate outliers, while white bars represent breaks in the $y$-axis. Light green columns represent females and dark green, males.

and $\mathrm{Cu}$ concentrations in muscle (Da Silva et al., 2014), CCL and $\mathrm{Cd}$ and $\mathrm{Zn}$ concentrations in kidney (Gordon et al., 1998), CCL and As in muscle and kidney (Saeki et al., 2000), as well as negative correlations between CCL and $\mathrm{Zn}, \mathrm{Cu}$ and $\mathrm{Cd}$ in kidney, positive correlation between CCL and Mn concentration in the same tissue, negative correlations between CCL and Mn and Hg concentration in muscle and positive correlation between CCL and $\mathrm{Cu}$ concentrations (Sakai et al., 2000) in green turtles. A trend toward negative correlations between elemental concentrations in kidney and muscle and body size in green turtles has been attributed to the previously mentioned ontogenic shift in diet observed in this species McKenzie et al. (1999). Thus, exposure to metals and a bioaccumulation trend may occur only in the initial phase of this species life, and subsequent growth and development would decrease contaminant loads, due to the "dilution effect" (Kamunde and Wood, 2003).

Statistically significant elemental concentration differences between the three juvenile individuals presenting fibropapillomatosis and healthy juveniles were observed only for $\mathrm{Cu}$, an essential element, in muscle. In this case, animals presenting the condition exhibited a means of $0.26 \pm 0.02 \mathrm{mg}$ $\mathrm{kg}^{-1}$, significantly lower than the mean for healthy individuals, of $1.82 \pm 0.20 \mathrm{mg} \mathrm{kg}^{-1}$. Although the exact etiology of fibropapillomatosis is not yet fully known, its multicausal nature is a consensus, and many studies suggest genetic predispositions, contamination by environmental contaminants, mainly polycyclic aromatic hydrocarbons and metals, alterations in chemical water parameters and the presence of the herpesvirus in the environment (Aguirre and Lutz, 2004; Da Silva et al., 2016). For example, reported high $\mathrm{Cu}$ and $\mathrm{Pb}$ concentrations (means of $1.32 \mu \mathrm{g} \mathrm{g}^{-1}$ and $1.44 \mu \mathrm{g} \mathrm{g}^{-1}$, respectively) in the blood of sea turtle individuals positively correlated to the inhibition of the activity of 3-hydroxy-3-methylglutaryl-CoA reductase, an enzyme that participates in the biosynthesis process of sterols, including cholesterol, which was detected at levels below normal in turtles affected by fibropapillomatosis. In addition, the authors suggest that oxidative stress caused by high $\mathrm{Fe}$ and $\mathrm{Pb}$ concentrations may be directly related to the cause and development of the disease. It is known that $\mathrm{Cu}$ is essential for optimal innate immune function, and that its deficiency results in decreased immune responses in several groups, such as mollusks, birds, and mammals (Blanco et al., 2004; Wang et al., 2009; Djoko et al., 2015), and that the reactivation of herpesvirus is closely correlated with the immune system, as the disease mainly occurs in immunocompromised individuals in several organisms (Schmader and Dworkin, 2008). Thus, it may stand to reason that the decreased $\mathrm{Cu}$ concentrations observed in the three individuals presenting fibropapillomatosis are related 


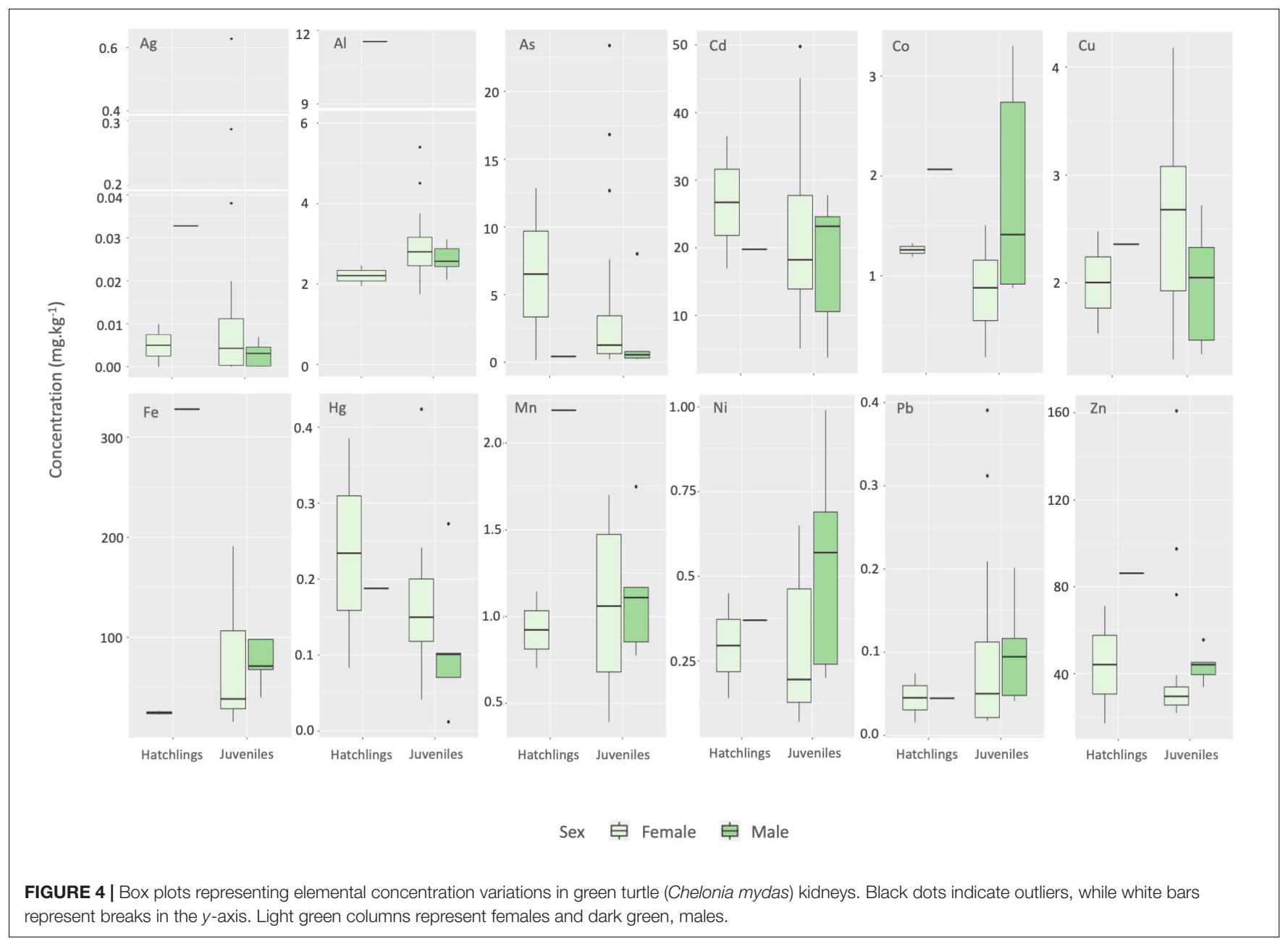

to decreased immune responses, activating this herpesvirus in green turtles, although further evaluations are required to verify this hypothesis.

Literature comparisons of studies conducted throughout the Brazilian coast are presented in Table 5. The kidney samples analyzed herein exhibited higher $\mathrm{Cd}, \mathrm{Mn}$, and Ni concentrations, with a notable difference related to $\mathrm{Cd}$ concentrations, and lower $\mathrm{Cu}$ concentrations when compared to Barbieri (2009), who evaluated samples obtained from the Cananeia estuary, a reportedly pristine area, with little or no metal pollution, which is probably the cause of the low metal concentrations detected in most of the assessed samples. $\mathrm{Cd}, \mathrm{Hg}, \mathrm{Pb}$, and $\mathrm{Zn}$, on the other hand, were considerably higher than reported by De Macêdo et al. (2015), which is interesting as those authors assessed a highly industrialized region on the northern coast of Bahia and expected to present high metal contamination levels. Cd and $\mathrm{Zn}$ levels were also considerably higher when compared to the kidney samples analyzed. Muscle samples analyzed herein contained lower $\mathrm{Ag}$ and $\mathrm{Pb}$ concentrations compared to values reported by Da Silva et al. (2014), and higher Cd, Cu, and Zn. All studies grouped both males and females, due to the aforementioned lack of statistical differences between feeding strategies. The study area evaluated by Da Silva et al. (2014) has seen a significant increase in urban, industrial and port activities in recent years, which may have contributed to increased metal concentration in the surrounding marine environment and, consequently, in sea turtles. In addition, the region suffers from the continuous and growing input of agricultural waste from the adjacent plantation area.

\section{Statistical Correlations Between Variables}

The strong and very strong significant $(p<0.05)$ inter-elemental Spearman correlations observed among sea turtle organs are exhibited in Table 6.

Metal and metalloid interactions within organisms are related to several physic-chemical and biotic aspects, such as chemical speciation in the environment, which may lead to preferential competitive environmental uptake and differential tissue affinity, as well as different metal detoxification routes, resulting in differential distribution patterns in animal tissues, which indicate that inter-elemental interactive effects should be considered in environmental monitoring and risk assessment evaluations (Norwood et al., 2003; Peterson et al., 2009; Yang et al., 2010). Therefore, investigations of statistically significant inter- 
TABLE 5 | Literature comparisons of metal concentrations $\left(\mathrm{mg} \mathrm{kg}^{-1}\right)$ in green turtle (Chelonia mydas) tissues conducted in other areas throughout the Brazilian coast.

\begin{tabular}{|c|c|c|c|c|c|c|c|c|c|c|c|c|c|c|c|}
\hline $\begin{array}{l}\text { Sampling } \\
\text { site }\end{array}$ & Tissue & Age & $\mathbf{A g}$ & Al & As & $\mathrm{Cd}$ & Co & $\mathrm{Cu}$ & $\mathrm{Fe}$ & $\mathrm{Hg}$ & Mn & $\mathrm{Ni}$ & $\mathrm{Pb}$ & $\mathrm{Zn}$ & References \\
\hline \multirow{4}{*}{$\begin{array}{l}\text { Região dos } \\
\text { Lagos, Rio } \\
\text { de Janeiro, } \\
\text { Brazil }\end{array}$} & \multirow[t]{2}{*}{ Kidney } & $\begin{array}{l}\text { Hatchlings (males } \\
\text { and females) }\end{array}$ & $\begin{array}{c}0.014 \pm \\
0.017\end{array}$ & $\begin{array}{c}5.321 \pm \\
5.394\end{array}$ & $\begin{array}{c}4.482 \pm \\
7.259\end{array}$ & $\begin{array}{c}24.418 \pm \\
10.573\end{array}$ & $\begin{array}{c}1.530 \pm \\
0.470\end{array}$ & $\begin{array}{c}2.122 \pm \\
0.516\end{array}$ & $\begin{array}{c}125.849 \pm \\
175.052\end{array}$ & $\begin{array}{c}0.219 \pm \\
0.153\end{array}$ & $\begin{array}{c}1.345 \pm \\
0.763\end{array}$ & $\begin{array}{c}0.321 \pm \\
0.165\end{array}$ & $\begin{array}{c}0.045 \pm \\
0.029\end{array}$ & $\begin{array}{c}58.204 \pm \\
36.257\end{array}$ & \multirow[t]{4}{*}{$\begin{array}{l}\text { Present } \\
\text { Study }\end{array}$} \\
\hline & & $\begin{array}{l}\text { Juveniles (males } \\
\text { and females) }\end{array}$ & $\begin{array}{c}0.049 \pm \\
0.146\end{array}$ & $\begin{array}{c}2.893 \pm \\
0.848\end{array}$ & $\begin{array}{c}3.850 \pm \\
6.387\end{array}$ & $\begin{array}{c}20.676 \pm \\
12.109\end{array}$ & $\begin{array}{c}1.096 \pm \\
0.742\end{array}$ & $\begin{array}{c}2.492 \pm \\
0.826\end{array}$ & $\begin{array}{c}73.153 \pm \\
55.937\end{array}$ & $\begin{array}{c}0.153 \pm \\
0.093\end{array}$ & $\begin{array}{c}1.071 \pm \\
0.402\end{array}$ & $\begin{array}{c}0.349 \pm \\
0.254\end{array}$ & $\begin{array}{c}0.100 \pm \\
0.101\end{array}$ & $\begin{array}{c}43.824 \pm \\
32.622\end{array}$ & \\
\hline & \multirow[t]{2}{*}{ Muscle } & $\begin{array}{l}\text { Hatchlings (males } \\
\text { and females) }\end{array}$ & $\begin{array}{c}0.000 \pm \\
0.000\end{array}$ & $\begin{array}{c}2.217 \pm \\
0.492\end{array}$ & $\begin{array}{c}5.359 \pm \\
8.659\end{array}$ & $\begin{array}{c}0.281 \pm \\
0.089\end{array}$ & $\begin{array}{c}0.037 \pm \\
0.036\end{array}$ & $\begin{array}{c}0.345 \pm \\
0.072\end{array}$ & $\begin{array}{c}17.029 \pm \\
12.018\end{array}$ & $\begin{array}{c}0.034 \pm \\
0.030\end{array}$ & $\begin{array}{c}0.002 \pm \\
0.004\end{array}$ & $\begin{array}{c}0.011 \pm \\
0.005\end{array}$ & $\begin{array}{c}0.003 \pm \\
0.001\end{array}$ & $\begin{array}{c}9.024 \pm \\
3.190\end{array}$ & \\
\hline & & $\begin{array}{l}\text { Juveniles (males } \\
\text { and females s) }\end{array}$ & $\begin{array}{c}0.046 \pm \\
0.143\end{array}$ & $\begin{array}{c}7.745 \pm \\
13.321\end{array}$ & $\begin{array}{c}6.981 \pm \\
12.546\end{array}$ & $\begin{array}{c}0.166 \pm \\
0.152\end{array}$ & $\begin{array}{c}0.023 \pm \\
0.205\end{array}$ & $\begin{array}{c}0.377 \pm \\
0.160\end{array}$ & $\begin{array}{c}25.112 \pm \\
36.266\end{array}$ & $\begin{array}{c}0.060 \pm \\
0.089\end{array}$ & $\begin{array}{c}0.148 \pm \\
0.503\end{array}$ & $\begin{array}{c}0.036 \pm \\
0.037\end{array}$ & $\begin{array}{c}0.011 \pm \\
0.019\end{array}$ & $\begin{array}{c}14.773 \pm \\
12.810\end{array}$ & \\
\hline \multirow{4}{*}{$\begin{array}{l}\text { Cananeia } \\
\text { Estuary, } \\
\text { São Paulo, } \\
\text { Brazil }\end{array}$} & \multirow[t]{2}{*}{ Kidney } & $\begin{array}{l}\text { Hatchlings (males } \\
\text { and females) }\end{array}$ & ND & ND & ND & ND & ND & ND & ND & ND & ND & ND & ND & ND & \multirow[t]{4}{*}{$\begin{array}{l}\text { Barbieri, } \\
2009\end{array}$} \\
\hline & & $\begin{array}{l}\text { Juveniles (males } \\
\text { and females) }\end{array}$ & ND & ND & ND & $\begin{array}{c}0.280 \pm \\
0.090\end{array}$ & ND & $\begin{array}{c}3.514 \pm \\
0.291\end{array}$ & ND & ND & $\begin{array}{c}1.070 \pm \\
0.204\end{array}$ & $\begin{array}{c}0.025 \pm \\
0.003\end{array}$ & ND & ND & \\
\hline & \multirow[t]{2}{*}{ Muscle } & $\begin{array}{l}\text { Hatchlings (males } \\
\text { and females) }\end{array}$ & ND & ND & ND & ND & ND & ND & ND & ND & ND & ND & ND & ND & \\
\hline & & $\begin{array}{l}\text { Juveniles (males } \\
\text { and females) }\end{array}$ & ND & ND & ND & ND & ND & ND & ND & ND & ND & ND & ND & ND & \\
\hline \multirow{4}{*}{$\begin{array}{l}\text { Arembepe } \\
\text { Beach, } \\
\text { Bahia, } \\
\text { Brazil }\end{array}$} & \multirow[t]{2}{*}{ Kidney } & $\begin{array}{l}\text { Hatchlings (males } \\
\text { and females) }\end{array}$ & ND & ND & ND & ND & ND & ND & ND & ND & ND & ND & ND & ND & \multirow[t]{4}{*}{$\begin{array}{l}\text { De Macêdo } \\
\text { et al., } 2015\end{array}$} \\
\hline & & $\begin{array}{l}\text { Juveniles (males } \\
\text { and females) }\end{array}$ & ND & $\begin{array}{c}19.488 \pm \\
16.156\end{array}$ & $\begin{array}{c}337.400 \pm \\
295.120\end{array}$ & $\begin{array}{c}15.260 \pm \\
5.936\end{array}$ & $\begin{array}{c}1.243 \pm \\
0.655\end{array}$ & $\begin{array}{c}3.808 \pm \\
1.820\end{array}$ & $\begin{array}{c}121.800 \pm \\
64.960\end{array}$ & $\begin{array}{c}0.101 \pm \\
0.039\end{array}$ & $\begin{array}{c}1.694 \pm \\
0.787\end{array}$ & $\begin{array}{c}0.538 \pm \\
0.395\end{array}$ & $\begin{array}{c}0.042 \pm \\
0.039\end{array}$ & $\begin{array}{c}42.280 \pm \\
5.880\end{array}$ & \\
\hline & \multirow[t]{2}{*}{ Muscle } & $\begin{array}{l}\text { Hatchlings (males } \\
\text { and females) }\end{array}$ & ND & $N D$ & ND & ND & ND & ND & ND & $N D$ & $N D$ & ND & ND & $N D$ & \\
\hline & & $\begin{array}{l}\text { Juveniles (males } \\
\text { and females) }\end{array}$ & ND & ND & ND & ND & ND & ND & ND & ND & ND & ND & ND & ND & \\
\hline \multirow{4}{*}{$\begin{array}{l}\text { Rio Grande } \\
\text { do Sul, } \\
\text { Brazil }\end{array}$} & \multirow[t]{2}{*}{ Kidney } & $\begin{array}{l}\text { Hatchlings (males } \\
\text { and females) }\end{array}$ & ND & ND & ND & ND & ND & ND & ND & ND & ND & ND & ND & ND & \multirow[t]{4}{*}{$\begin{array}{l}\text { Da Silva } \\
\text { et al., } 2014\end{array}$} \\
\hline & & $\begin{array}{l}\text { Juveniles (males } \\
\text { and females) }\end{array}$ & $\begin{array}{c}0.115 \pm \\
0.014\end{array}$ & ND & ND & $\begin{array}{c}7.924 \pm \\
0.644\end{array}$ & ND & $\begin{array}{c}3.416 \pm \\
0.308\end{array}$ & ND & ND & ND & ND & $\begin{array}{c}1.512 \pm \\
0.112\end{array}$ & $\begin{array}{c}15.204 \pm \\
1.148\end{array}$ & \\
\hline & \multirow[t]{2}{*}{ Muscle } & $\begin{array}{l}\text { Hatchlings (males } \\
\text { and females) }\end{array}$ & ND & ND & ND & ND & ND & ND & ND & ND & ND & ND & ND & ND & \\
\hline & & $\begin{array}{l}\text { Juveniles (males } \\
\text { and females) }\end{array}$ & $\begin{array}{c}0.084 \pm \\
0.021\end{array}$ & $N D$ & ND & $\begin{array}{c}0.084 \pm \\
0.021\end{array}$ & ND & $\begin{array}{c}0.252 \pm \\
0.042\end{array}$ & ND & ND & ND & ND & $\begin{array}{c}0.882 \pm \\
0.063\end{array}$ & $\begin{array}{c}3.486 \pm \\
0.273\end{array}$ & \\
\hline
\end{tabular}

ND, Non-determined. Results reported as dry weight were transformed to wet weight considering $72 \%$ and $79 \%$ water content for kidney and muscle water content, respectively (Godley et al., 1999$)$. 
TABLE 6 | Significant $(p<0.05)$ inter-elemental Spearman correlations observed between sea turtle organs.

\begin{tabular}{lcc}
\hline Association & Correlation coefficient & Strength \\
\hline As K $\times$ As M & 0.924 & Very strong \\
$\mathrm{Hg} \mathrm{K} \times \mathrm{Hg} \mathrm{M}$ & 0.833 & Strong \\
$\mathrm{Ni} \mathrm{M} \times \mathrm{Pb} \mathrm{M}$ & 0.808 & Strong \\
$\mathrm{As} \mathrm{K} \times \mathrm{Hg} \mathrm{K}$ & 0.733 & Strong \\
\hline
\end{tabular}

K, kidney; $M$, muscle.

and intra-organ correlations are paramount in performing biological inferences. These associations have been previously suggested as indicative of common exposure sources, storage pathways and/or detoxification routes (Ribeiro et al., 2009; Jerez et al., 2013).

In the present study, all statistically significant associations were positive and either strong or very strong, although only between toxic elements ( $\mathrm{As}, \mathrm{Ni}, \mathrm{Hg}$, and $\mathrm{Pb}$ ). Elemental associations between different organs indicate transport between tissues (Erasmus, 2004; Hauser-Davis et al., 2020) and are important to assess potentially deleterious effects and bioaccumulation or excretion processes. As all associations detected herein were positive, probable synergistic effects and similar sources for different elemental pairs in the same organ are postulated (e.g., $\mathrm{Ni}$ and $\mathrm{Pb}$ in muscle, and $\mathrm{As}$ an $\mathrm{Hg}$ in kidney). On the other hand, As and $\mathrm{Hg}$ present in both, kidney and muscle, seem to indicate inter-tissue transport and muscle bioaccumulation, as described previously.

\section{CONCLUSION}

The data reported herein includes baseline levels for both green turtle hatchlings and for $\mathrm{Al}, \mathrm{As}, \mathrm{Co}, \mathrm{Fe}, \mathrm{Hg}, \mathrm{Mn}$, and $\mathrm{Ni}$ in muscle tissue for juvenile and hatchling green sea turtles, as no studies concerning metal levels in hatchling kidney and muscle samples are available for Brazil and $\mathrm{Al}, \mathrm{As}, \mathrm{Co}, \mathrm{Fe}, \mathrm{Hg}, \mathrm{Mn}$, and $\mathrm{Ni}$ have not yet been determined in muscle for any age in green turtle specimens in Brazil. The establishment of these baseline elemental data is extremely valuable and paramount for biomonitoring efforts and, consequently, conservation measures for this threatened species, furthering knowledge on environmental elemental contamination in this species geographic distribution range.

No differences were observed between male and female element loads in kidney or liver, corroborating other literature reports, and generally higher metal concentrations in juveniles were observed compared to hatchlings for $\mathrm{Ag}, \mathrm{Al}, \mathrm{Cu}, \mathrm{Fe}, \mathrm{Hg}$, $\mathrm{Ni}, \mathrm{Pb}$, and $\mathrm{Zn}$, probably due to the ontogenic dietary shifts that occur in this species.

Statistically significant lower $\mathrm{Cu}$ concentrations in the three juvenile individuals presenting fibropapillomatosis were observed compared to healthy juveniles, which may indicate decreased immune functions and adequate herpesvirus activation in green turtles. Further assessments concerning other contaminants, such as polycyclic aromatic hydrocarbons, also implicated in the etiology of this disease are, thus, required to further evaluate potentially associated factors to this condition.

In addition, probable synergistic effects and similar sources for the $\mathrm{Ni}-\mathrm{Pb}$ and $\mathrm{As}-\mathrm{Hg}$ toxic element pairs in green turtle muscle and kidney, respectively, are postulated, as well as inter-tissue transport between kidney and muscle and muscle bioaccumulation of $\mathrm{As}$ and $\mathrm{Hg}$, which may be the result of a highly contaminated environment in the Campos Basin.

In sum, constant green sea turtles monitoring in this region is required, in order to aid in the conservation this species and maintain the ecological balance of marine environments. Furthermore, contaminant monitoring is also necessary aiming at both environmental and human health risk assessments and decision-making.

\section{DATA AVAILABILITY STATEMENT}

The original contributions presented in the study are included in the article/supplementary material, further inquiries can be directed to the corresponding author.

\section{ETHICS STATEMENT}

Ethical review and approval was not required for the animal study because no ethics committee authorization in Brazil is required for the analyses of animals found dead. Authorization for sampling and analyses of the stranded sea turtles was given by the Brazilian Ministry of Environment (ABIO license no. 861/2017).

\section{AUTHOR CONTRIBUTIONS}

DB: conceptualization, resources, data curation, visualization, investigation, formal analysis, and writing - original draft. IW and LP: data curation, visualization, and formal analysis. RR: validation, data curation, and formal analysis. TS: validation, resources, funding acquisition, supervision, and writing - draft reviewing. PB: data curation, resources, funding acquisition, and writing - draft reviewing. AS and AT: data curation, resources, and validation. FC and ES: conceptualization, resources, project administration, supervision, and writing draft reviewing. LL: formal analysis, conceptualization, supervision, writing - original draft, and writing - draft reviewing. SS: conceptualization, resources, funding acquisition, project administration, supervision, and writing - draft reviewing. RH-D: conceptualization, resources, investigation, validation, data curation, formal analysis, project administration, supervision, writing - original draft, and writing - draft reviewing. All authors contributed to the article and approved the submitted version.

\section{FUNDING}

This study was financed in part by the Coordenação de Aperfeiçoamento de Pessoal de Nível Superior - Brazil (CAPES) - Finance Code 001. 


\section{ACKNOWLEDGMENTS}

Sea turtles were sampled through the beach monitoring project (PMP-BC/ES) between the states of Rio de Janeiro and Espírito Santo, Brazil. This project is part of the requirements established by the federal environmental licensing process of the Brazilian

\section{REFERENCES}

Aguilar, A., Borrell, A., and Reijnders, P. J. H. (2002). Geographical and temporal variation in levels of organochlorine contaminants in marine mammals. Mar. Env. Res. 53, 425-452. doi: 10.1016/S0141-1136(01)00128-3

Aguirre, A. A., and Lutz, P. L. (2004). Marine turtles as sentinels of ecosystem health: is fibropapillomatosis an indicator? EcoHealth 1, 275-283.

Aguirre, A. A., Balazs, G. H., Spraker, T. R., Murakawa, S. K., and Zimmerman, B. (2002). Pathology of oropharyngeal fibropapillomatosis in green turtles Chelonia mydas. J. Aquat. Anim. Health 14, 298-304. doi: 10.1577/154886672002014<0298:POOFIG $<2.0$. CO 2

Arthur, K. E., Boyle, M. C., and Limpus, C. J. (2008). Ontogenetic changes in diet and habitat use in green sea turtle (Chelonia mydas) life history. Mar. Ecol. Prog. Series 362, 303-311.

Baird, C. (2002). Química Ambiental. Porto Alegre Inmetro: ArtMed Editora.

Barbieri, E. (2009). Concentration of heavy metals in tissues of green turtles (Chelonia mydas) sampled in the Cananéia estuary, Brazil. Braz. J. Oceanogr 57, 243-248. doi: 10.1590/S1679-87592009000300007

Becker, D. S., and Bigham, G. N. (1995). Distribution of mercury in the aquatic food web of Onondaga Lake, New York. In Mercury as a Global Pollutant. Dordrecht: Springer, 563-571.

Bezerra, M. F., Lacerda, L. D., Costa, B. G., and Lima, E. H. (2012). Mercury in the sea turtle Chelonia mydas (Linnaeus, 1958) from Ceará coast, NE Brazil Anais da Academia Brasileira de Ciências 84, 123-128. doi: 10.1590/S000137652012005000002

Bjorndal, K. A. (1997). "Foraging ecology and nutrition of sea turtles," in The biology of sea turtles, eds P. L. Lutz and J. A. Musick (London: CRC Press), 199-231

Blanco, G., Jimenez, B., Frias, O., Millan, J., and Davila, J. A. (2004). Contamination with nonessential metals from a solid-waste incinerator correlates with nutritional and immunological stress in prefledgling black kites (Milvus migrans). Env. Res. 94, 94-101. doi: 10.1016/S0013-9351(03)00120-8

Bryman, A., and Cramer, D. (2011). Quantitative data analysis with IBM SPSS 17, 18 and 19. Routledge.

Cardona, L., Campos, P., Levy, Y., Demetropoulos, A., and Margaritoulis, D. (2010). Asynchrony between dietary and nutritional shifts during the ontogeny of green turtles (Chelonia mydas) in the Mediterranean. J. Exp. Mar. Biol. Ecol. 393, 83-89. doi: 10.1016/j.jembe.2010.07.004

Caurant, F., Bustamante, P., Bordes, M., and Miramand, P. (1999) Bioaccumulation of cadmium, copper and zinc in some tissues of three species of marine turtles stranded along the French Atlantic coasts. Mar. Pollut. Bull. 38, 1085-1091. doi: 10.1016/S0025-326X(99)00109-5

Da Silva, C. C., Klein, R. D., Barcarolli, I. F., and Bianchini, A. (2016). Metal contamination as a possible etiology of fibropapillomatosis in juvenile female green sea turtles Chelonia mydas from the southern Atlantic Ocean. Aquat. Toxicol. 170, 42-51. doi: 10.1016/j.aquatox.2015.11.007

Da Silva, C. C., Varela, A. S. Jr., Barcarolli, I. F., and Bianchini, A. (2014) Concentrations and distributions of metals in tissues of stranded green sea turtles (Chelonia mydas) from the southern Atlantic coast of Brazil. Sci. Total Env. 466, 109-118. doi: 10.1016/j.scitotenv.2013.06.094

Da Silva, M. L., Castro, R. O., Sales, A. S., and de Araújo, F. V. (2018). Marine debris on beaches of Arraial do Cabo, RJ, Brazil: An important coastal tourist destination. Mar. Pollut. Bull.130, 153-158. doi: 10.1016/j.marpolbul.2018 03.026

De Jesus, T. B., and de Carvalho, C. E. V. (2008). Utilização de biomarcadores em peixes como ferramenta para avaliação de contaminação ambiental por mercúrio (Hg). Oecologia Brasiliensis 12:7.
Environmental Agency (IBAMA), for the exploration of oil and gas by PETROBRAS at the Campos Basin Province. The metal and metalloid results were obtained directly in research using different laboratory and techniques from those adopted by PMP-BC/ES. TS acknowledges CNPq and FAPERJ for the granted scholarships.

De la Lanza-Espino, G. J., Hernández Pulido, S., and Carbajal Pérez, J. L. (eds). (2000). Organismos Indicadores de la Calidad del Agua y de la Contaminación (Bioindicadores). Ph.D. thesis, Plaza y Valdés Editores, Distrito Federal, México. De Macêdo, G. R., Tarantino, T. B., Barbosa, I. S., Pires, T. T., Rostan, G. Goldberg, D. W., et al. (2015). Trace elements distribution in hawksbill turtle (Eretmochelys imbricata) and green turtle (Chelonia mydas) tissues on the northern coast of Bahia, Brazil. Mar. Pollut. Bull. 94, 284-289. doi: 10.1016/j. marpolbul.2015.02.033

Decataldo, A., Di Leo, A., Giandomenico, S., and Cardellicchio, N. (2004). Association of metals (mercury, cadmium and zinc) with metallothionein-like proteins in storage organs of stranded dolphins from the Mediterranean Sea (Southern Italy). J. Env. Monitor. 6, 361-367. doi: 10.1039/B315685K

Djoko, K. Y., Cheryl-lynn, Y. O., Walker, M. J., and McEwan, A. G. (2015). The role of copper and zinc toxicity in innate immune defense against bacterial pathogens. J. Biol. Chem. 290, 18954-18961. doi: 10.1074/jbc.R115.647099

Erasmus, C. P. (2004). The Concentration of Ten Metals in the Tissues of Shark Species Squalus Megalops and Mustelus Mustelus (Chondrichthyes) Occuring Along the Southeastern Coast of South Africa. Doctoral Dissertation, University of Port Elizabeth, Port Elizabeth.

Eurachem. (1998). The Fitness for Purpose of Analytical Methods. Eurachem. Guide 1998:59. doi: 978-91-87461-59-0

Formia, A., Deem, S., Billes, A., Ngouessono, S., Parnell, R., Collins, T., et al. (2007) Fibropapillomatosis confirmed in Chelonia mydas in the Gulf of Guinea, West Africa. Mar. Turtle Newsletter 116:20.

Fossi, M. C., and Marsili, L. (2003). Effects of endocrine disruptors in aquatic mammals. Pure Appl. Chem. 75, 2235-2247. doi: 10.1351/pac200375112235

Frazer, N. B., and Ehrhart, L. M. (1985). Preliminary growth models for green, Chelonia mydas, and loggerhead, Caretta caretta, turtles in the wild. Copeia 1985, 73-79. doi: 10.2307/1444792

Gardner, S. C., Fitzgerald, S. L., Vargas, B. A., and Rodríguez, L. M. (2006). Heavy metal accumulation in four species of sea turtles from the Baja California peninsula. Mexico. Biometals 19, 91-99.

Godley, B. J., Thompson, D. R., and Furness, R. W. (1999). Do heavy metal concentrations pose a threat to marine turtles from the Mediterranean Sea. Mar. Pollut. Bull. 38, 497-502. doi: 10.1016/S0025-326X(98)00184-2

Gordon, A. N., Pople, A. R., and Ng, J. (1998). Trace metal concentrations in livers and kidneys of sea turtles from south-eastern Queensland, Australia. Mar. Freshwater Res. 49, 409-414. doi: 10.1071/MF97266

Guimarães, S. M., Gitirana, H. M., Wanderley, A. V., Monteiro-Neto, C., and LoboHajdu, G. (2013). Evidence of regression of fibropapillomas in juvenile green turtles Chelonia mydas caught in Niterói, southeast Brazil. Dis. Aquat. Org. 102, 243-247. doi: 10.3354/dao02542

Hall, M., Forrester, L. M., Parker, D. K., Grover, P. L., and Wolf, C. R. (1989) Relative contribution of various forms of cytochrome P450 to the metabolism of benzo [a] pyrene by human liver microsomes. Carcinogenesis 10, 1815-1821. doi: $10.1093 /$ carcin/10.10.1815

Hauser-Davis, R. A., Pereira, C. F., Pinto, F., Torres, J. P. M., Malm, O., and Vianna, M. (2020). Mercury contamination in the recently described Brazilian whitetail dogfish Squalus albicaudus (Squalidae, Chondrichthyes). Chemosphere 2020:126228. doi: 10.1016/j.chemosphere.2020.126228

Heppell, S. S., Snover, M. L., and Crowder, L. B. (2003). "Sea turtle population ecology," in The biology of sea turtles, eds P. L. Lutz, J. A. Musick, and J. Wyneken (Washington, DC: CRC Press).

Herbst, L. H. (1994). Fibropapillomatosis of marine turtles. Annu. Rev. Fish Dis. 4, 389-425. doi: 10.1016/0959-8030(94)90037-X

Inmetro (2016). Orientação Sobre Validação de Meitodos Analiiticos: Documento de Caraiter Orientativo. DOQ-CGCRE-008. Brasília: Inmetro. 
Ishak, I., Rosli, F. D., Mohamed, J., and Ismail, M. F. M. (2015). Comparison of digestion methods for the determination of trace elements and heavy metals in human hair and nails. Malaysian J. Med. Sci. MJMS 22:11.

IUCN. (2020). IUCN Red List of Threatened Species. Available online at: http: //www.iucnredlist.org (accessed October 31, 2020).

Jerez, S., Motas, M., Benzal, J., Diaz, J., and Barbosa, A. (2013). Monitoring trace elements in Antarctic penguin chicks from South Shetland Islands, Antarctica. Mar. Pollut. Bull. 69, 67-75. doi: 10.1016/j.marpolbul.2013.01.004

Kamunde, C., and Wood, C. M. (2003). The influence of ration size on copper homeostasis during sublethal dietary copper exposure in juvenile rainbow trout, Oncorhynchus mykiss. Aquatic Toxicol. 62, 235-254. doi: 10.1016/S0166445X(02)00101-7

Keller, J. M., Balazs, G. H., Nilsen, F., Rice, M., Work, T. M., and Jensen, B. A. (2014). Investigating the potential role of persistent organic pollutants in Hawaiian green sea turtle fibropapillomatosis. Env. Sci. Technol. 48, 7807-7816. doi: 10.1021/es5014054

Limpus, C. J., Limpus, D. J., Arthur, K. E., and Parmenter, C. J. (2005). Mon- itoring of green turtle population dynamics in Shoalwater Bay: 2000-2004. Townsville: Research Publication No. 83, Great Bar- rier Reef Marine Park Authority Research Publication Series.

Marcovaldi, M. Â, and Dei Marcovaldi, G. G. (1999). Marine turtles of Brazil: the history and structure of Projeto TAMAR-IBAMA. Biolog. Conserv. 91, 35-41. doi: 10.1016/S0006-3207(99)00043-9

Marcovecchio, J. E. (2000). Overview on land-based sources and activities affecting the marine, coastal and associated freshwater environment in the Upper Southwest Atlantic Ocean. UNEP Reg. Seas Rep. Stud. 170, 2000.

Marijić, V. F., Dragun, Z., Perić, M. S., Kepčija, R. M., Gulin, V., Velki, M., et al. (2016). Investigation of the soluble metals in tissue as biological response pattern to environmental pollutants (Gammarus fossarum example). Chemosphere 154, 300-309. doi: 10.1016/j.chemosphere.2016. 03.058

Marins, R. V., Lacerda, L. D., Paraquetti, H. H. M., De Paiva, E. C., and Boas, R. V. (1998). Geochemistry of mercury in sediments of a sub-tropical coastal lagoon, Sepetiba Bay, southeastern Brazil. Bull. Env. Contaminat. Toxicol. 61, 57-64. doi: $10.1007 / \mathrm{s} 001289900729$

McKenzie, C., Godley, B. J., Furness, R. W., and Wells, D. E. (1999). Concentrations and patterns of organochlorine contaminants in marine turtles from Mediterranean and Atlantic waters. Mar. Env. Res. 47, 117-135. doi: 10.1016/S0141-1136(98)00109-3

Melo, G. J. (2003). Congresso brasileiro de geoquímica, IX, 2003, Belém. Poluição química das águas. Belém.

Miller, G. G., Sweet, L. I., Adams, J. V., Omann, G. M., Passino-Reader, D. R., and Meier, P. G. (2002). In vitro toxicity and interactions of environmental contaminants (Arochlor 1254 and mercury) and immunomodulatory agents (lipopolysaccharide and cortisol) on thymocytes from lake trout (Salvelinus namaycush). Fish shellfish Immunol. 13, 11-26. doi: 10.1006/fsim.2001. 0381

Musick, J. A., and Limpus, C. J. (1997). "Habitat utilization and migration in juvenile sea turtles," in The Biology of Sea Turtles, eds P. L. Lutz and J. A. Musick (Boca Raton, Florida: CRC Press), 137-163.

Norwood, W. P., Borgmann, U., Dixon, D. G., and Wallace, A. (2003). Effects of metal mixtures on aquatic biota: a review of observations and methods. Human Ecol. Risk Assess. 9, 795-811. doi: 10.1080/713610010

Peterson, S. A., Ralston, N. V., Peck, D. V., Sickle, J. V., Robertson, J. D., Spate, V. L., et al. (2009). How might selenium moderate the toxic effects of mercury in stream fish of the western US? Env. Sci. Technol. 43, 3919-3925. doi: 10.1021/ es803203g

Prior, B., Booth, D. T., and Limpus, C. J. (2015). Investigating diet and diet switching in green turtles (Chelonia mydas). Aust. J. Zool. 63, 365-337. http://dx.doi.org/10.1071/ZO15063,

$\mathrm{R}$ Core Team (2019). R: A language and environment for statistical computing.Vienna: R Core Team

Reich, K. J., Bjorndal, K. A., and Bolten, A. B. (2007). The "lost years" of green turtles: Using stable isotopes to to study cryptic lifestage. Biol. Lett. 3, 712-714.

Ribeiro, A. R., Eira, C., Torres, J., Mendes, P., Miquel, J., Soares, A. M. V. M., et al. (2009). Toxic element concentrations in the razorbill Alca torda (Charadriiformes, Alcidae) in Portugal. Arch. Envir. Cont. Toxicol. 56, 588-595.

Saeki, K., Sakakibara, H., Sakai, H., Kunito, T., and Tanabe, S. (2000). Arsenic accumulation in three species of sea turtles. Biometals 13, 241-250.

Sakai, H., Saeki, K., Ichihashi, H., Kamezaki, N., Tanabe, S., and Tatsukawa, R. (2000). Growth-related changes in heavy metal accumulation in green turtle (Chelonia mydas) from Yaeyama Islands, Okinawa, Japan. Arch. Environ. Cont. Toxicol. 39, 378-385.

Schmader, K. E., and Dworkin, R. H. (2008). Natural history and treatment of herpes zoster. J. Pain. 9(Suppl. 1), 3-9.

Stokes, H. J., Mortimer, J. A., Hays, G. C., Unsworth, R. K. F., Laloë, J. O., and Esteban, N. (2019). Green turtle diet is dominated by seagrass in the Western Indian Ocean except amongst gravid females. Mar. Biol. 166:135.

Taylor, V., Goodale, B., Raab, A., Schwerdtle, T., Reimer, K., Conklin, S., et al. (2017). Human exposure to organic arsenic species from seafood. Sci. Total Env. 580, 266-282. doi: 10.1016/j.scitotenv.2016.12.113

USP (2013). Elemental Impurities - Procedures, 38-NF 33 second supplement. Available online at: https://www.usp.org/sites/default/files/usp/document/ourwork/chemical-medicines/key-issues/c233.pdf . (Accessed date 09, July 2020)

Wang, W., Mai, K., Zhang, W., Ai, Q., Yao, C., Li, H., et al. (2009). Effects of dietary copper on survival, growth and immune response of juvenile abalone, Haliotis discus hannai Ino. Aquaculture 297, 122-127. doi: 10.1016/j.aquaculture.2009. 09.006

Wyneken, J. (2001). The anatomy of sea turtles. U.S. Department of Commerce NOAA Technical Memorandum NMFS-SEFSC-470. Washington, D.C: NOAA. $1-172$.

Yang, D. Y., Xu, Y., Chen, Y. W., and Belzile, N. (2010). Inverse relationships between selenium and mercury in tissues of young walleye (Stizosedion vitreum) from Canadian boreal lakes. Sci. Total Env. 408, 1676-1683. doi: 10.1016/j. scitotenv.2009.11.049

Conflict of Interest: PB was employed by BW Consultoria Veterinária. AS and AT were employed by CTA Serviços em Meio Ambiente.

The remaining authors declare that the research was conducted in the absence of any commercial or financial relationships that could be construed as a potential conflict of interest.

Copyright (c) 2021 Bruno, Willmer, Pereira, Rocha, Saint'Pierre, Baldassin, Scarelli, Tadeu, Correia, Saggioro, Lemos, Siciliano and Hauser-Davis. This is an open-access article distributed under the terms of the Creative Commons Attribution License (CC BY). The use, distribution or reproduction in other forums is permitted, provided the original author(s) and the copyright owner(s) are credited and that the original publication in this journal is cited, in accordance with accepted academic practice. No use, distribution or reproduction is permitted which does not comply with these terms. 